\title{
A STUDY OF DIGITAL MARKETING TOOLS USAGE HABITS AMONG HUNGARIAN TOURISTS
}

\author{
Eva HAPP \\ Széchenyi István University, Faculty of Business Department of Tourism, Hungary, e-mail: happ.eva@ sze.hu \\ Zsuzsanna IVANCSÓNÉ HORVÁTH \\ Széchenyi István University, Faculty of Business Department of Tourism, Hungary, e-mail: ivancso.zsuzsa@ sze.hu
}

\begin{abstract}
Citation: Happ, E., \& Horváth Ivancsóné, Z. (2020). A STUDY OF DIGITAL MARKETING TOOLS USAGE HABITS AMONG HUNGARIAN TOURISTS. GeoJournal of Tourism and Geosites, 32(4), 1283-1289. https://doi.org/10.30892/gtg.32414-570
\end{abstract}

\begin{abstract}
Digitalisation has become inevitable these days. It has been in the forefront due to innovations, the development of information technology tools, internet and smartphones transforming the tourism industry, too. Digital marketing tools and methods have attracted an increasing interest among the Hungarian tourists, as well. The study focuses on the spread of these opportunities in Hungary. The paper's aim is to investigate when and in what way Hungarian tourists participate in digital tourism. Secondary and primary research was conducted between October 2018 and March 2019 with a sample of more than 500 respondents. The results show how Hungarian tourists are related to the digital development in tourism. This study also explores the link between the risk of the activities and the usage of online tools. The study advances into the literature about the importance of digitalisation in tourism. It shows specifically where service providers need to pay close attention in the marketing communication, in order to remain competitive and gain a competitive advantage.
\end{abstract}

Key words: digital tourism, digital tools, digital services, e-tourism

$* * * * * *$

\section{INTRODUCTION}

Digitalisation is an increasingly important area in all sectors including tourism. The development of new technologies is the basis for the development of e-tourism, and simultaneously it has prompted the increase of its influence in recent years (Korinth et al., 2019). The past decade has seen the rapid development of digital tourism in many countries. There are new, innovative methods and tools to help tourists get involved in every step of the tourism buying process. As digitalisation is driven by the consumer, the process of digitalisation is unstoppable in tourism as well (Szigetvári, 2018a). Previous studies have reported about smart tourism (Lopez De Avila, 2015), e-tourism (Buhalis, 2003), and digital tourism (Benyon et al., 2014), as well. The previous study of the authors has sought to determine a model of the complexity of the digital tourism (Happ and Ivancsóné Horváth, 2018).

In Hungary, there has been little quantitative analysis of the supply and demand side of the tourism market regarding digital tools and methods. This indicates a need to understand the various perception of digital tools and methods that exist on the Hungarian market. On the one hand, it is an important issue for service providers if they are able to adapt to the digitalisation process, in which areas and in what depth innovative solutions are being applied. On the other hand, it is significant to investigate which digital tools and methods are being adopted by tourists and how often they use them. The major objective of this study was to investigate the prevalence of the tools and methods used by Hungarian tourists, the digital consumption habits, which was examined by a survey along the model created and published earlier by the authors (Happ and Ivancsóné Horváth, 2018). This research seeks to address the following question: In what areas are Hungarian tourists most likely to use online tools and methods? Both secondary and primary types of research were used in this investigation. Data from the supply side of the tourism market were collected with the help of secondary research.

The primary research focused on the travel-related online activities, concentrating on the consumer side. The primary research was conducted in the form of a survey, with data being gathered via Internet. This study offers some important insights into Hungarian tourist's habits of using digital marketing tools. The findings provide relevant perceptions for the service providers, as well.

\section{THEORETICAL BACKGROUND}

\section{Definitions}

The first time we see digitisation is in the field of information technology. Digitisation is the process of converting material (text, image, sound) already existing in another medium into an encoded form, readable by computer ${ }^{1}$. However, digitalisation is a complex concept that involves many interdependent processes and made of different steps for almost every organisation. Digitalisation in business means the use of digital technologies that ensure a change in business model and build up new revenue and value-creating opportunities. Digitalisation also occurs in tourism, which primarily involves the use of modern infocommunication tools and technologies. Tourism based on the use of ICT (Information and Communication Technology) tools appears in the literature under various names. The term 'smart' is used more and more for technological, economic and social development generated by sensors, big data, open data, new connectivity methods and information exchange. According to Höjer and Wangel (2014), what is called "smart" technology is not so much the unique technology development, but rather the interconnection, synchronisation and coordinated use of different technologies. The term "smart" is also used in connection with the operation of cities (intelligent or smart city), where it refers to activities aimed at the use of innovative technologies to achieve resource optimisation, efficient and equitable management, sustainability and to reach a better quality of life (Gretzel et al., 2015, Kim and Kim, 2017). The term is also used in connection with tourism. Smart tourism is made up of three main components that are built on infocommunication tools: smart destinations, smart experiences and smart business system (Lopez De Avila, 2015). The essence of e-tourism is the use of ICT in all sectors of tourism. According to Buhalis (2003), e-tourism is "the digitalisation of all processes and value chains of

\footnotetext{
* Corresponding author

${ }^{1}$ Digitize: Definition of Digitize by Oxford Dictionary on Lexico.com also meaning of Digitize. (n.d.). Retrieved June 13, 2020, from https://en.oxforddictionaries.com/definition/digitize
} 
tourism and hospitality that enable organisations to maximise impact and efficiency" (Buhalis, 2003; Buhalis, 2011:6). E-tourism, as a type of e-commerce, is an industry based on the selling and marketing of products and services through an electronic system. Like e-commerce, etourism includes electronic data transfer, distribution management, e-marketing (online marketing), online transactions, electronic data interchange, management systems and automated data collection. In addition, e-tourism is complemented with special activities of tourism, such as the virtual presence of tour operators, travel agents and other tourism professionals. E-tourism for consumers includes e-information, e-booking (hotels, transport, etc.) and electronic payment (Buhalis and Jun, 2011; Sion and Mihãlcescu, 2013).

The meaning of digital tourism is linked to the support of tourism experiences with digital tools (Benyon et al., 2014). The term digital tourism includes the use of all information communication tools and IT solutions that help to meet the needs of tourists and improve the competitiveness of organisations and enterprises operating in the field of tourism. All three terms have almost the same content from different perspectives (Happ and Ivancsóné Horváth, 2018).

\section{The place, role and significance of digital services in tourism}

Digitalisation, though first appeared in connection with bookings - starting with airline tickets and then accommodation -, is nowadays present in all areas of tourism. A paradigm shift happened and a new era of tourism, the period of digital tourism, has start ed that goes beyond the previously understood consumer orientation, as it not only takes into account the needs of the consumer, but they are now actively involved in the marketing processes by the interconnection of digital devices and their networks.

Consumers are now involved in product design, as well as real-time price development. The main venue of sales is the online/virtual space, and online communication takes the first place in building relationships with the consumer, which at the same time means a personalised message that fits the customer's profile. The function of the model is influenced by the consumer, the consumer behaviour and the tourist profiles defined within it (Happ and Ivancsóné Horváth, 2018). Placing the e-elements of digital tourism in a common illustration, the complexity of the digitalisation process in tourism can also be observed (Figure. 1).

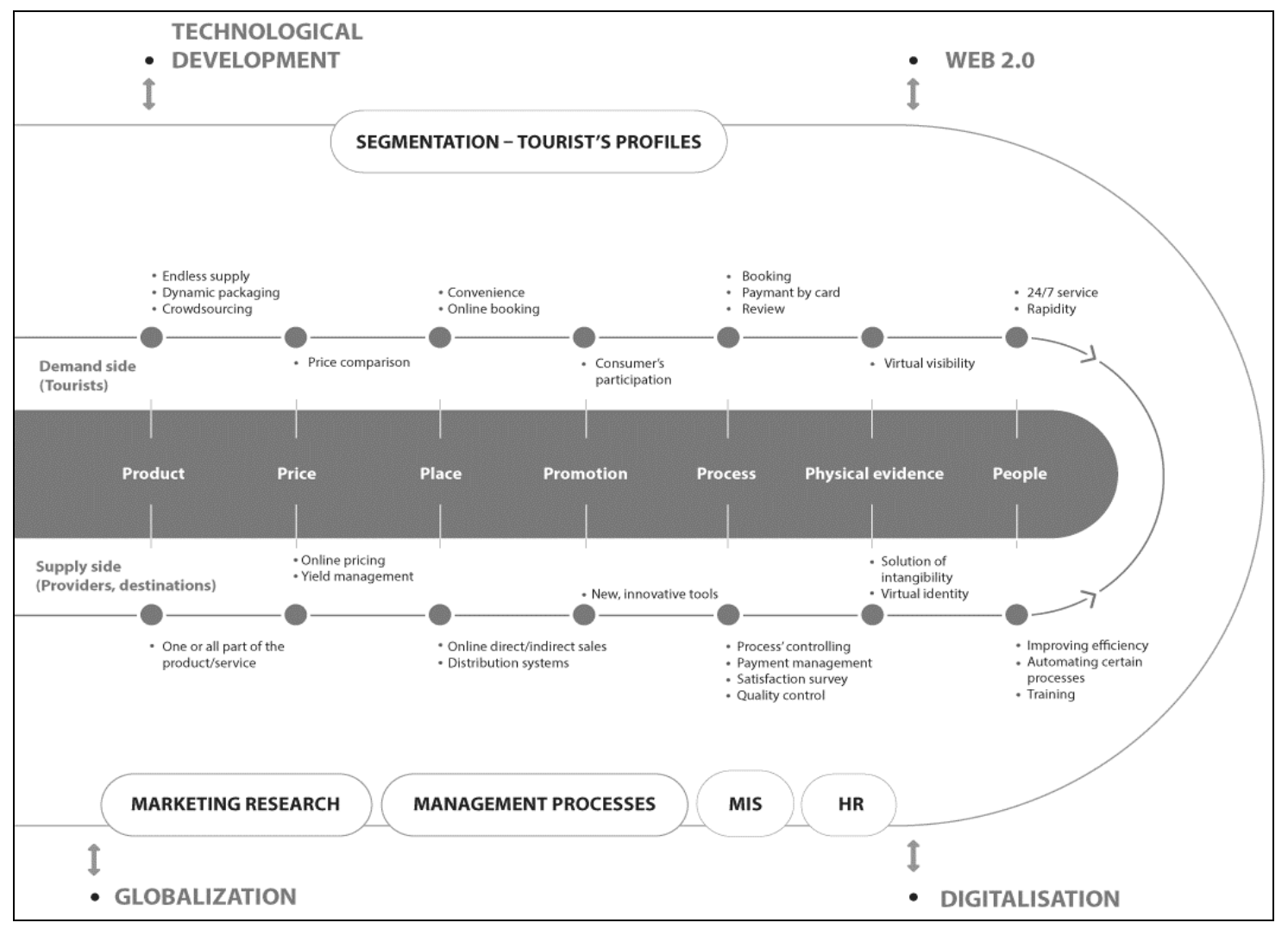

Figure 1. The model of digital tourism in a marketing-oriented approach (Source: Happ and Ivancsóné Horváth, 2018)

\section{Digital tools and methods}

There are several examples of the use of digital technologies in tourism. Innovative methods appear primarily in the innovation of products and services, but they can also be found in the design of sales channels and the sales process. The digital tools and technologies, which are already in use in tourism, are summarized in Table 1.

\section{Digital tourism in Hungary}

Different conditions must be met for the development of digital tourism. We examine the technological conditions typical of Hungary and present the current state of digital tourism using secondary sources. Investigating the current situation, we analyse data from e-tourism, which includes both online reservations and online travel ticket purchases.

\section{Technological conditions}

Development of online commerce requires that consumers have adequate internet access. The proportion of Internet users is constantly increasing, as is the number of people in possession of digital devices. The proportion of Internet users in Hungary was $81.0 \%$ in 2018 , which is the 42nd highest Internet penetration rate among the countries of the world. This value is higher than the European-Central Asian average of $79.4 \%$ (Staffa et al., 2019). The number of mobile phone subscriptions is also close to the world average, with 122.5 mobile subscribers per 100 people in Hungary (Staffa et al., 2019). 
A Study of Digital Marketing Tools Usage Habits Among Hungarian Tourists

\begin{tabular}{|c|c|}
\hline Tools & Examples \\
\hline Online booking sites & eg. Booking.com, szallas.hu, airbnb.com \\
\hline OTAs (online travel agency) & eg. Expedia, eDreams, cTrip.com \\
\hline Distribution systems & eg. Amadeus, Galileo, Sabre, Worldspan \\
\hline Online payment systems & eg. OTP, Paypal, Transfer wise, We Pay \\
\hline Online check in and check out & hotels, airports \\
\hline Front Office systems & eg. Hostware, Hotelgram \\
\hline Revenue management softwares & eg. Hostware, Hotel Yield Software - Xotels, Hotelgram \\
\hline Channel manager & eg. Siteminder, Hotelogix \\
\hline Online price comparison (metasearch) sites & eg. Trivago, HotelsCombined, Kayak \\
\hline Online user satisfaction measures & NPS (Net Promoter Score) Wootric \\
\hline Audio-guide & eg. museums, exhibitions \\
\hline Own websites & every service provider in tourism \\
\hline Virtual concierge & hotels, Concierge 4nt he Go \\
\hline Smartphone systems in hotels & eg. Think Labs, Handy \\
\hline Digital key & eg. Accor Hotels \\
\hline Social media sites & Facebook, Instagram, Twitter, etc. \\
\hline Tourism applications & maps, tour guide, search engine \\
\hline \multicolumn{2}{|l|}{ Wi-fi } \\
\hline Online marketing tools & eg. Google Adwords, Google Analytics, Moz \\
\hline \multicolumn{2}{|l|}{ VR-glasses } \\
\hline \multicolumn{2}{|l|}{ Bionic contact lenses } \\
\hline Smart hotel & KViHotel \\
\hline Robots & field of housekeeping \\
\hline Introduction of workflow handling softwares & hotelkit.net, digital bookkeeping programs \\
\hline Smart home control & iNels \\
\hline
\end{tabular}

Table 1. Digital tools and methods in tourism (Source: own research; Gelter, 2017)

\section{Digital commerce}

In Hungary, mostly the younger generation is using online commerce for shopping. Older generations prefer traditional stores in their shopping process. Digital commerce means revenue from e-commerce, e-tourism, e-services, digital media, and connected car markets.

In Europe, the share of digital spending within per capita consumer spending in 2019 reached 5.8\%. This proportion is 5.2\% in Hungary. Digital commerce revenue expected in Hungary in 2019, broken down by group, is as follows: e-commerce 56.3\%, e-tourism $37.3 \%$, eservices $3.2 \%$, digital media $2.8 \%$, connected car $04 \%$. E-commerce has the highest share of digital commerce revenue (56.3\%) with $€$ $1,852,9$ million in digital revenue. E-tourism also has an outstanding share of about $€ 1,227$ million (Staffa et al., 2019).

\section{E-Tourism}

The e-tourism market is dominated by the sale of online services and digital products over the Internet. The definition includes online travel reservations (packages, hotels) and tickets booked for travelling such as airline tickets, coach tickets, train tickets, car rental and other travel services. Ticket booking or buying may be carried out both on desktop or mobile devices (smartphones or tablets).

Looking at the Hungarian data (Figure 2), a steadily growing forecast can be observed for digital tourism revenue over the next 5 years.

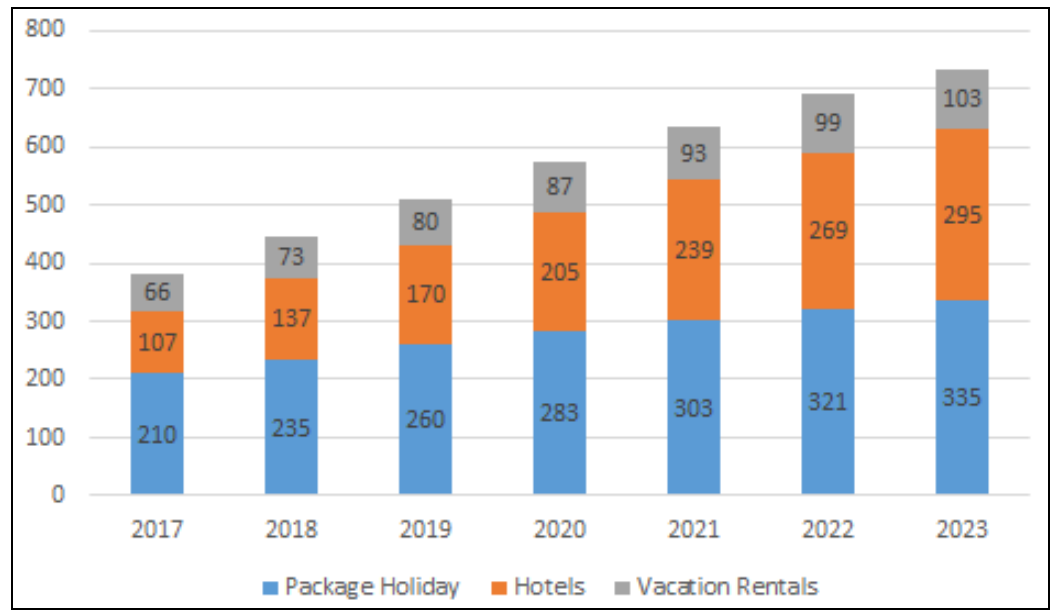

Figure 2. Revenue in the Online Travel Booking market in Hungary (in million $€$ ) (Source: Statista Mobility Market Outlook, 2019)

According to the forecast, online revenue is expected to grow steadily in both online booking and online ticketing, however, the growth is expected to slow down from 2020 onwards. At the same time, e-tourism revenue could reach $€ 1.845$ million by 2023 (Statista Mobility Market Outlook, 2019). The same changes can be observed in the number of users as well. It is expected that by 2020 approximately 2 million consumers will use the online options when booking, both for accommodation and travel tickets. Online booking users are projected to reach $22.4 \%$, while online ticket purchases to reach $27.5 \%$.

Average revenue per user (ARPU) for online booking may increase from $€ 253.6$ in 2017 to $€ 344.44$ in 2023. Considering the purchase of online travel tickets, this amount is projected to increase from $€ 312.96$ to $€ 424.57$.

Based on e-tourism revenues, on the TOP5 rankings the US is expected to have the highest revenue in 2019, with a market share of approximately $€ 235,085$ million. Hungary's expected revenue from digital tourism is $€ 1,229$ million (Statista Mobility Market Outlook, 2019). It is worth analysing e-tourism by markets as well, that is studying the data and changes in the fields of online booking and online ticketing. 


\section{Online reservations}

Online booking includes holiday packages, hotel stays and private holiday apartments booked through the Internet. Online payment process is a prerequisite for this segment. Regardless of the number of travellers, users represent the person who made the booking. Wellknown providers of travel packages include online travel agencies (OTAs) such as Expedia and Opodo, and tour operators such as TUI and Thomas Cook. Special online booking sites for hotels and private accommodation include Hotels.com, Booking.com and Airbnb.

Online accommodation booking will continue to grow in all surveyed areas over the next few years, but hotel bookings in particular are showing outstanding growth rates. With a market share of around $€ 1,488$ million in 2019 , the US generates the largest revenue. The highest share of users in the online hotel booking market is in Sweden (37.4\%). The number and proportion of Hungarian users is much lower (18.3\%). Online accommodation booking forecasts suggest that revenue and user numbers are expected to continue to grow in the coming years. Average spending by users is also expected to grow year by year. Statistical data show that online hotel reservations are the most popular among the 25-34-year-olds (24.6\%) and the 35-44-year-olds (24.7\%) in Hungary (Statista Mobility Market Outlook, 2019).

\section{Online travel ticket purchase}

The online ticketing group includes flights, coaches and online train tickets, as well as car rentals and car sharing services (Uber, Lyft) booked with the use of Internet. These services are booked directly through the service providers' website or through online travel agencies (OTAs). When determining the number of users, we take into account the number of ticket purchasers, regardless of how many travellers are included in each booking. Worldwide, similarly to hotel bookings, the US is the first in purchase of online tickets as well, with expected revenues of $€ 143.597$ million by 2019. The highest proportion of users is in Sweden (43.7\%). This proportion is $20.7 \%$ in Hungary.

The online ticket market in Hungary is expected to grow at an average annual rate of $11.6 \%$ between 2019 and 2023 , bringing the revenue of the surveyed area to over $€ 1$ billion by the end of the period. The largest segment of online transport services is airline ticket purchase, with around 2 million users expected by 2023. The users of the services typically belong to younger age groups, with approximately $67 \%$ of them are under 45 years of age (Statista Mobility Market Outlook, 2019).

\section{RESEARCH OBJECTIVE, METHODOLOGY AND DATA}

Secondary research data show the extent of materialisation of e-tourism. The aim of our primary research was to survey the spread of the tools and methods used by Hungarian consumers, that is, their digital consumption habits. This is investigated with the help of a model, the $7 \mathrm{P}$, created by the authors and presented earlier (Figure 1).

The research was conducted between October 2018 and March 2019 through an online questionnaire survey. Within the given period, 539 respondents completed the questionnaire. The questions are partly related to the use of digital devices and partly to travel habits, including the use of digital devices in relation to travelling. Descriptive statistical methods (frequency, maximum, minimum, mode, median), cross-table analysis and chi-squared test were applied for the statistical analysis.

\section{Presentation of the sample}

Table 2 presents the characteristics of the sample. The table summarises and breaks down the results by gender, age and place of residence as well as respondents' own perceptions of their income situation.

\begin{tabular}{|l|c|}
\hline \multicolumn{2}{|c|}{ Characteristics of the sample (\%) } \\
\hline Gender distribution & 32,4 \\
\hline Male & 67,6 \\
\hline Female & 7,8 \\
\hline Age distribution & 38,3 \\
\hline Baby boomer & 38,0 \\
\hline X-generation & 15,9 \\
\hline Y-generation & 23,5 \\
\hline Z-generation & 31,6 \\
\hline Place of residence & 28,9 \\
\hline Capital City & 16 \\
\hline County seat & 0,1 \\
\hline City & 3 \\
\hline Village & 21,4 \\
\hline Education & 75,5 \\
\hline Primary school (Grade 8) or less & \\
\hline Vocational school & 59,8 \\
\hline Vocational high school or secondary school matriculation & 30 \\
\hline College or university & 8,3 \\
\hline Respondents' perception of their income situation & 1,9 \\
\hline Live well from income, can put money aside & \\
\hline Live well from income, but cannot put money aside & \\
\hline Barely make ends meet & \\
\hline Cannot make ends meet & \\
\hline
\end{tabular}

Table 2. Presentation of the research sample

\section{RESULTS AND DISCUSSION}

We present the research results along the logic of 7P, with the provision that first the results of general digital device use will be introduced.

\section{Owning and using a digital device}

In our study, we first examined what kind of digital devices respondents have. Based on the responses, we found that there is an increasing tendency that people prefer mobile devices among digital devices. This will certainly help to further digitise tourism from a consumer perspective. Laptops and tablets are taking the place of desktop computers.

At the same time, smart phones have almost completely displaced traditional cell phones as well as cameras. The challenge for service providers is no longer the digital presence - though in some places it still is - but applications optimised for different devices. It is interesting to note that no correlation could be found between the ownership of digital assets and the economic situation of respondents based on their 
own perception. Although the contingency table, which was set up during the contingency analysis shows a shift in the number of assets held towards a better economic situation, this result cannot be considered as significant. However, it is proven that the tools are available for online activities and our studies show that respondents are actively using it. It was also found that the communication with other people has shifted to the online platform in the highest level, but information search and shopping are gaining ground as well.

\section{Product policy from the consumer side}

In the context of e-tourism, we first examined the consumer side of product policy. Accordingly, the extent to which digital solutions are used by tourists in travel organising. Information search $(93.1 \%)$ and online booking $(83.5 \%)$ were most often cited as online travel arrangements in the process. More than half (55.8\%) of the respondents organise their entire trip using their digital devices, and the online purchase of airline tickets is also frequent $(47.1 \%)$. However, the process is still incomplete, as while nearly half of those surveyed buy airline tickets online, not even one-third $(29.9 \%)$ do the check-in online. The least used online service among those surveyed is car hire. Only $18.4 \%$ of respondents had already rented a car this way. At the same time, the highest rate of rejection can also be observed here, as $16 \%$ said they would definitely not rent a car online again.

\section{Price examination by tourists}

It is well-known that Hungarian consumers are price sensitive, so the possibility of price comparison is important. 86\% of the respondents of the survey most of the time use online price comparisons when organising their travel. 406 people, $75 \%$ of the surveyed consider this opportunity important. They mostly use Tripadvisor to see this factor, but it is also common to check the same offer on different sites.

\section{Process management from the consumer side}

A representative survey by Intrum claims management company, published by MTI Hungarian News Agency, reveals that Hungarian population is quite distrustful with online payment and they rather use cash (Szabó, 2019). According to our research, Hungarian consumers use online payment at a much higher rate than expected (Figure 3), but it was also noticeable that consumers are more courageous to use online activities where payment is not a necessary part of the process. As a result of the survey, we can say that the majority of respondents have already used and will continue to use online payment in the future. This is indispensable to achieve not only information collection and sharing to happen online.

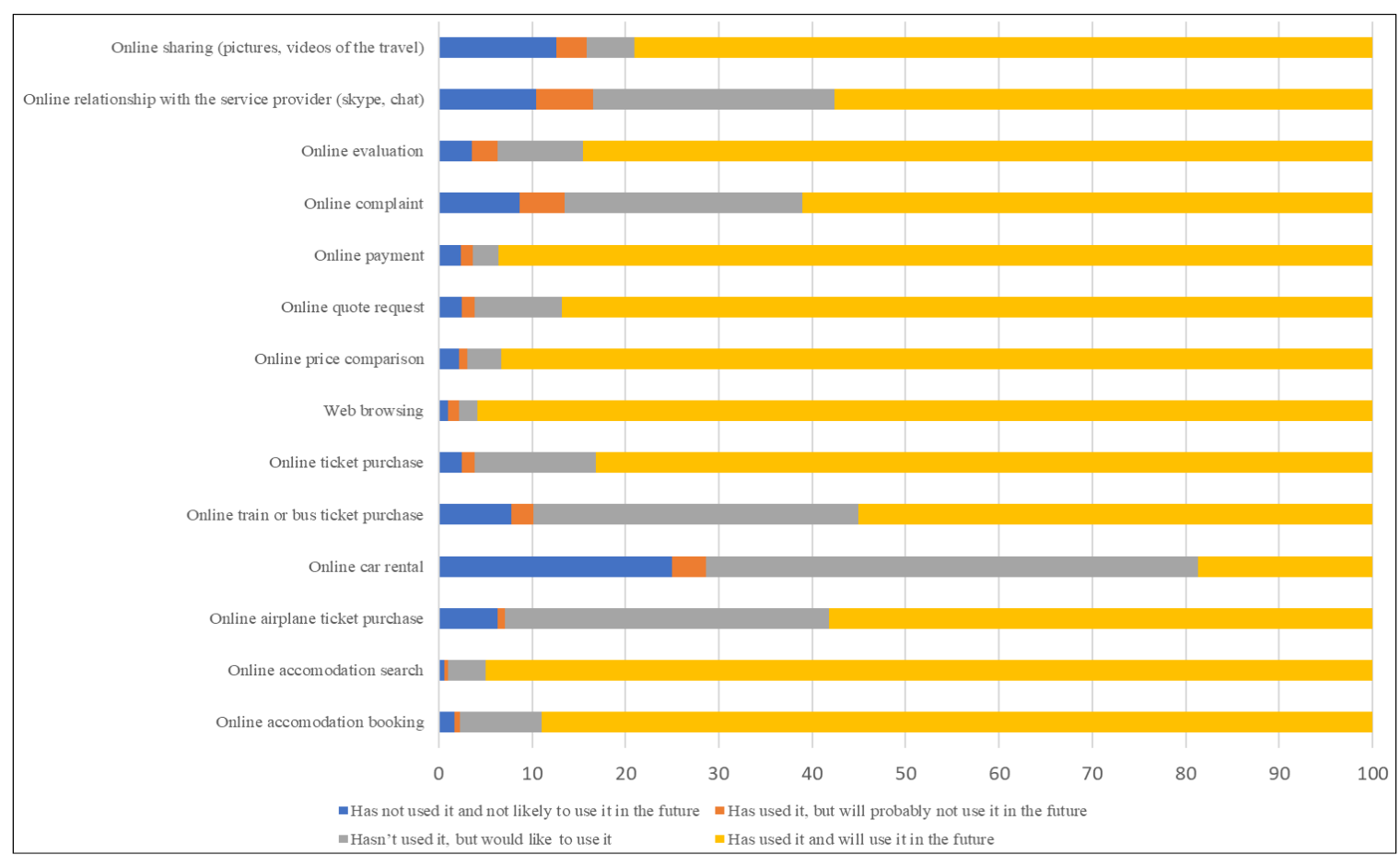

Figure 3. Tourism-related online activities among the respondents $(n=539)$

The results clearly show that the higher the risk (we cannot complete the transaction when buying a plane, train or bus ticket, or the process of car rental without payment), the less of the process is realised online. In most cases, booking can be cancelled, paid on the spot, all of which increase the sense of security, reduce the risk for the consumer, and thus increase the frequency of use.

The language of the interface can also influence consumers' online activities. It is known that the Hungarian population does not have the best language knowledge, so processes that are only available in foreign languages are overshadowed.

Another conspicuous result is that respondents rather contact with the service provider and file complaints in person or through traditional means (telephone), than online.

\section{Point and mode of sale from consumer perspective}

Traditions of travel bookings have changed radically over the last 30 years. However, these changes make it even easier to bridge greater geographic distances. The search for information has largely shifted to online tools, which can be observe in our research as well. At the same time, most hotel bookings and ticket purchases to various means of public transport are mainly made online (Figure 3 ).

Nowadays, consumers can choose between direct and indirect channels when booking, and in both cases there is a possibility to book online and offline as well. In 2013, eNet had already written in a study that almost half of hotel bookings were made online (ENet., 2013). Since then, this situation has shifted even further towards the online booking. Within online sales, according to research by Szállás.hu and 
HOTREC (Szigetvári, 2018b, Turizmus.com, 2018), from 2013 to 2015, the proportion of direct hotel bookings dropped from 59.4\% to $55.2 \%$, while the share of OTAs increased from $19.3 \%$ to $22.3 \%$ and by 2018 , it even increased to $26.1 \%$.

Results of our research show that while respondents are happy to use direct online reservation systems, such as booking via the provider's own website or in e-mail, the channels most frequently used by them are already the OTAs, in Hungary mainly szallas.hu and booking.com (Figure 4). The preference for booking through travel agent companies and in person is very low among the respondents.

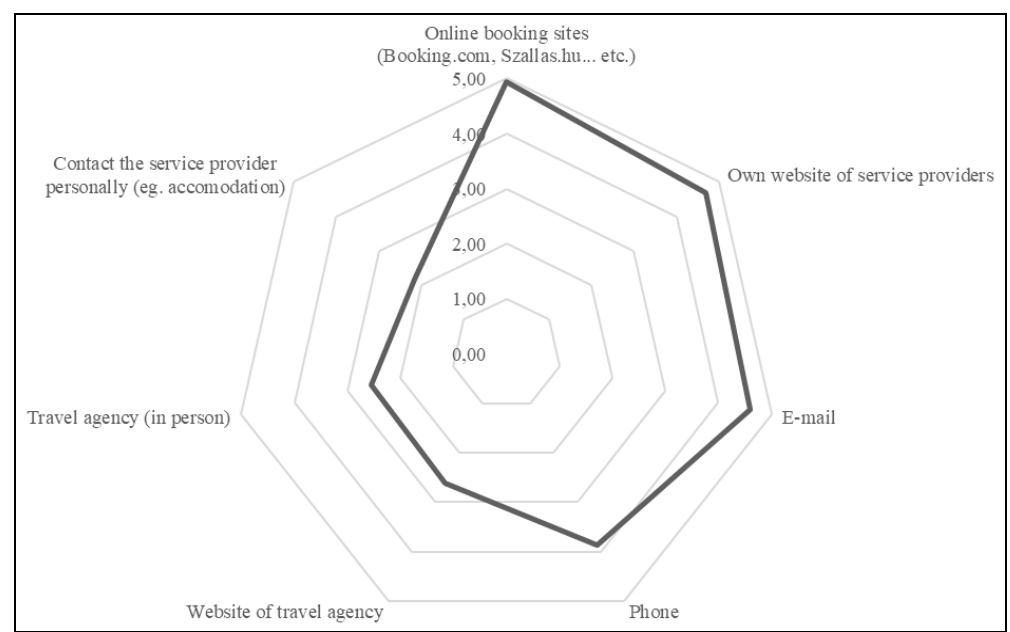

Figure 4. Preferences of different direct and indirect, online and offline sales channels $(n=539)$

\section{Marketing Communications}

The influence of marketing communication channels on consumer travel decisions was measured by scaling questions in the survey. The reliability of the scale was confirmed by a Cronbach alpha value of 0.725 .

When making travel decisions, respondents are most likely to consider service evaluations, but the own website of service providers is also an important factor. The research also confirmed the need for providers to pay attention to consumer ratings, as travel planners typically read online reviews when organising a trip. That is why it is very surprising that only $63 \%$ of the accommodation providers are prepared, and those who are behind, have inadequate or no website, thus $73 \%$ of the bookings that have been started are lost.

Feedback is essential for all service providers, as it facilitates important, perceptible improvements to the consumer and help in the correction of errors (Molnar and Moraru, 2017; Moraru, 2017). The questionnaire survey shows that the easier it is to express an opinion, the more likely people will use it. While usually $73.3 \%$ of respondents, 393 people, evaluate the service with scoring, only 33\% (177) are willing to give a rating in writing, only one quarter $(25,7 \%)$ write in the guest book, and $22.8 \%$ complete the local questionnaire.

The reverse is also true, mostly numerical ratings influence the travel decisions of the respondents (Figure 5). Opinions shared in forums and word of mouth advertising are also important, but the scoring of the services is paramount. We found a significant correlation between the gender of respondents and the extent to which they are influenced by online opinions in their travel decisions. It can be observed that women are much more likely to read and take into account the opinions of others about a service.

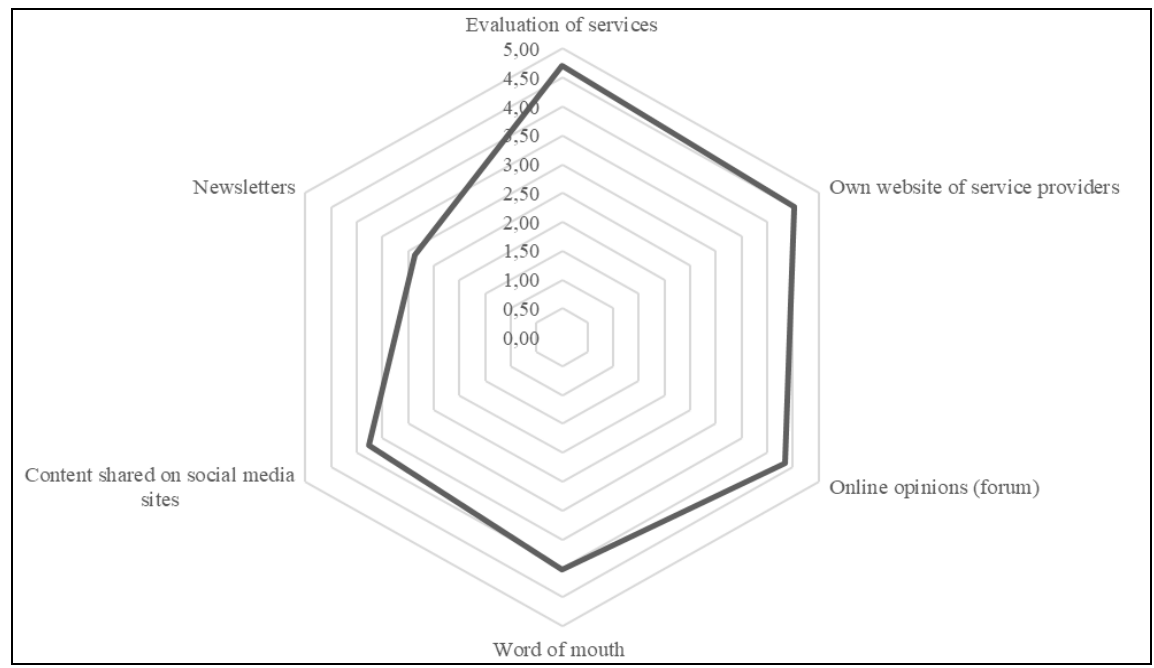

Figure 5. Influence of travel decisions (measured on a 1-5 scale) $(\mathrm{n}=539)$

\section{Examination of the human factor}

The presence of man in services, as we have already written, is essential in some areas of the service process, and although there are attempts to fully replace human work, there are several questions that can demonstrate that this is not yet feasible.

The attitudes of tourists regarding the different opportunities of e-tourism were measured on a 5-point Likert scale. The reliability of the scale, according to Cronbach's alpha value $(0.773)$ is satisfactory. Results showed that respondents were reluctant to try an unmanned hotel and would not stay in a hotel where robots help in the workload of the staff.

The age of the respondents significantly influenced the answers when judging online activities. Statistical analyses revealed that for some services, the importance of personal contact is perceived differently by respondents of different age categories. Requesting a quote and using 
a service are two factors where personal contact is clearly important for the older generations. In line with the demands of the $\mathrm{Y}$ and $\mathrm{Z}$ generations, personal contact is key when getting information, but it is also essential in sales and problem management.

VR glasses are very popular with young people, but it is reassuring that respondents would still watch the attractions live even if they were available in virtual form as well. According to the research of Korinth et al. (2019) the vast majority (approximately 2/3) of the respondents claim that following a virtual tour of a certain place, they are more likely to visit it. However, virtual reality has not yet gained much ground in our country. This can be attributed to the alienation of the technology and the small amount of VR in tourism available. There is already a significant correlation with age - of course, towards young people, they prefer to use "virtual walks".

\section{CONCLUSION}

In our work, we examined e-tourism based on our previously published model (Happ and Ivancsóné Horváth, 2018).

First, we introduced the concept of e-tourism and then summarised the digital tools and technologies used in tourism (Table 1). We examined our country regarding Internet penetration and mobile subscriptions compared to Europe, Central Asia and the United States of America. The data of Statista Country Report (Staffa et al., 2019) show that everything is given on the technical and technological side for Hungarian travellers to take advantage of the opportunities provided by e-tourism. According to Statista Country Report (Staffa et al., 2019), young people have already been taking advantage of these opportunities. According to the trends of the Statista Mobility Market Outlook (2019), the proportion of the users of online services and their average spending show a slow, constant increase in Hungary.

Online bookings forecast a growth in all surveyed areas over the next few years, but primarily hotel bookings demonstrate a remarkable growth rate. However, in Hungary the proportion of online hotel bookings (18.3\%) is significantly lower than that in the leading countries, similarly to online ticket purchases, which is $20.7 \%$ in Hungary compared to $43.7 \%$ in Sweden. Statistical data show that online reservation is the most popular among people aged between 25 and $34(24.6 \%)$ as well as those aged between 35-44 (24.7\%) in Hungary.

The aim of our primary research was to survey the prevalence of devices and methods used by Hungarian consumers, i.e. to reveal the digital behaviour of consumers with a questionnaire based on the model we created and presented earlier (Figure 1). Our questionnaire was completed by 539 respondents. We have found that the vast majority of people have the digital tools they need to participate in e-tourism. Of these, mobile devices are increasingly preferred among the respondents, so the challenge for service providers is no longer the digital presence, but applications optimised for different devices.

More than half of the respondents organise their entire trip using their digital devices, and the purchase of online airline tickets are also frequent. According to our research, respondents use online payment in a much higher rate than we have expected based on previous literature, but it is also observable that consumers are more courageous to use online activities where payment is not a nece ssary part of the process. The results indicate that the greater the consumer's risk perception of the activity, the less it is realised online. For some activities, such as making a complaint, personal contact is essential, but in general consumers cannot accept the staff-less robotic hotels yet.

In the area of marketing communication, the service providers' own website plays an extremely important role, as it is still the most used channel following online booking sites. Service providers also need to pay close attention to online reviews, although our survey shows that consumers are reluctant to write lengthy reviews, they are happy to score and most of them are looking at the revi ews of others before making their travel decisions. Finally, we have also found that, although virtual reality is very popular, especially among young people, personal experiences cannot be replaced by the virtual world yet.

\section{REFERENCES}

Benyon, D., Quigley, A., O’Keefe, B., \& Riva, G. (2013). Presence and digital tourism. Ai \& Society, 29(4), 521-529. https://doi.org/10.1007/s00146-013-0493-8

Buhalis, D. (2003). ETourism: Information technology for strategic tourism management. London: Pearson Education.

Buhalis, D., \& Jun, S. (2011). E-Tourism. UK: Bournemouth University.

Kim, D. \& Kim, S. (2017). The Role of Mobile Technology in Tourism: Patents, Articles, News, and Mobile Tour App Reviews November 2017 Sustainability. 9(11), 2082, https://doi.org/10.3390/su9112082

Gelter, H. (2017). Digital tourism - An analysis of digital trends in tourism and customer digital mobile behavior for the Visit Arctic Europe project. http://www.lme.fi/media/vae-outcomes/rd-results/report-visit-arctic-europe-mission-3-summary-2.pdf

Gretzel, U., Sigala, M., Xiang, Z., \& Koo, C. (2015). Smart tourism: Foundations and developments. Electronic Markets, 25(3), 179-188. https://doi.org/ $10.1007 / \mathrm{s} 12525-015-0196-8$

Happ, E., \& Ivancsóné Horváth, Zs. (2018). Digital tourism is the challenge of future. Knowledge Horizons - Economics, 10(2), 9-16.

Höjer, M., \& Wangel, J. (2014). Smart Sustainable Cities: Definition and Challenges. Advances in Intelligent Systems and Computing ICT Innovations for Sustainability, 333-349. https://doi.org/10.1007/978-3-319-09228-7_20

Korinth, B., Berdenov, Z., Pashkov, S.V., \& Wendt, J.A. (2019). The perception of VR of the tourists visiting chosen cultural facilities in Gdansk. Economic Problems of Tourism, 1/2019 (45), 63-72. https://doi.org/10.18276/ept.2019.1.45-06

Lopez De Avila, A. (2015). Smart Destinations: XXI Century Tourism. Presented at the ENTER2015 Conference on Information and Communication Technologies in Tourism, Lugano, Switzerland, February 4-6, 2015.

Molnar E., \& Moraru R. (2017). Content Analysis of Customer Reviews to Identify Sources of Value Creation in the Hotel Environment. In: Za S., Drăgoicea M., Cavallari M. (eds) Exploring Services Science. IESS 2017. Lecture Notes in Business Information Processing, vol. 279, Springer, Cham. https://doi.org/10.1007/978-3-319-56925-3_20

Moraru, R.C. (2017). Social value of online information in the hotel industry. In Proceedings of the International Conference on Business Excellence, Sciendo 11, (1) 810-817. https://doi.org/10.1515/picbe-2017-0086

Sion, B., \& Mihãlcescu, C. (2013). The Impact and Perspectives of the E-Tourism at a Global Level. Romanian Economic and Business Review, 8(4SI), $289-297$.

Staffa, V. \& Mälki, T. \& Sánchez, O., \& Mesloh, M. (2019). Hungary 2019. Retrieved June 13, 2020, from https://www.statista.com/study/48386/hungary/

Szabó, D. (2019). Bankkártyás fizetés: A magyarok szeretnek a középkorban élni. [Credit card payment: Hungarians like to live in the Middle Ages] Retrieved June 13, 2020, from https://www.napi.hu/magyar_vallalatok/bankartya-fizetes-keszpenz-intrum-felmeres-statisztika.682515.html

Szigetvári J. (2018a). CEO of szallas.hu, deep interview (June 8, 2018).

Szigetvári J. (2018b). Digital tourism. Presented at the International Tourism Conference, Széchenyi István University, Kautz Gyula Faculty of Business, Györ, November 16, 2018.

*** Digitize: Definition of Digitize by Oxford Dictionary on Lexico.com also meaning of Digitize. (n.d.). Retrieved June 13, 2020, from https://en. oxforddictionaries.com/definition/digitize

*** ENet. (2013). ENet. Retrieved June 13, 2020, from http://www.enet.hu/hirek/a-szallasfoglalas-csaknem-fele-interneten-tortenik/?lang=hu

*** Statista Mobility Market Outlook (2019). Travel \& Tourism - Hungary, Retrieved June 13, 2020, from https://www.statista.com/outlook/359/139/ etravel/hungary

*** Turizmus.com (2018). Tarol az online a szálláshely-szolgáltatók piacán. [Online wins on the hospitality market] (2018, April 20). Retrieved June 13, 2020, from https://turizmus.com/szallashely-vendeglatas/tarol-az-online-a-szallashely-szolgaltatok-piacan-1157231 